\title{
Effect of autoclaving on the formation of resistant starch from two Nigeria Cassava (Manihot esculenta) varieties
}

\author{
1,*Abioye, V.F., ${ }^{1}$ Adeyemi, I.A., ${ }^{1}$ Akinwande, B.A, ${ }^{2}$ Kulakow, P. and ${ }^{2}$ Maziya-Dixon, B. \\ ${ }^{1}$ Department of Food Science and Engineering, LAUTECH, Ogbomoso, Oyo State, Nigeria \\ ${ }^{2}$ International Institute of Tropical Agriculture, Ibadan, Nigeria
}

Article history:

Received: 8 July 2018

Received in revised form: 10

August 2018

Accepted: 18 August 2018

Available Online: 31 August 2018

Keywords:

Cassava starch,

Autoclaving,

Debranching,

Isoamylase,

Resistant starch.

DOI:

https://doi.org/10.26656/fr.2017.2(5).205

\begin{abstract}
This study evaluated the effect of autoclaving process on the production of resistant starch (RS) from cassava starch. RS was prepared by debranching, autoclaving and storage of cassava starch from two Nigeria varieties (TMS 30572 and TMS 98/0581). Starch suspensions were prepared with different starch water ratios $(1: 1 ; 1: 3$; and 1:5), debranched with isoamylase, autoclaved at 110 and $121^{\circ} \mathrm{C}$ for four heat and cool cycles, stored under refrigeration and freezing condition for $48 \mathrm{~h}$. Debranching process increased RS by about $73-78 \%$. Higher RS was obtained at higher temperature and with significant difference $(p<0.05)$ from each other. RS increased with storage time from 6.23 to 9.60 and 22.40 to $25.77 \mathrm{~g} / 100 \mathrm{~g}$ for undebranched and debranched samples, respectively, after $48 \mathrm{~h}$. This study indicated the potentials of these Nigeria cassava varieties in the production of RS which could serve as functional food.
\end{abstract}

\section{Introduction}

There is a greater awareness on the part of consumers of the relationship between nutrition and health which has led to the popularity of novel foods with good nutritional and health potentials (Azzurra and Paola, 2009). There is growing interest in novel foods with substances that promote health such as resistant starch. Resistant starch (RS) has been defined as the sum of starch and products of starch breakdown that is not absorbed in the small intestine of healthy individuals (Englyst et al., 1992; Muir et al., 1993; Öztürk and Koksel, 2014). It reaches to the colon and then fermented by beneficial microorganisms in the colon, resulting in the production of short chain fatty acids mainly acetic, propionic and butyric acids (Baghurst et al., 1996). They directly affect the large intestine by decreasing the $\mathrm{pH}$ value, which prevents the growth of pathogenic microorganisms and increases the potential for mineral absorption. Fatty acids stimulate colonic blood flow and increase nutrient flow (Haralampu, 2000; Topping and Clifton, 2001; Schwiertz et al., 2002; Champ, 2004; Chun-Ho et al., 2013).

The slow hydrolysis of RS makes it useful for the slow release of glucose, which can be especially useful in controlling glycemic plasma responses (Raben et al., 1994). RS is a non-caloric food component that does not contribute to the increase in blood glucose. In this, it has physiological effects in the human body that are similar to that of dietary fiber, which has been shown to reduce risks for some diseases, including colon cancer, coronary heart disease and glycemia (Ranhotra et al., 1996; Champ et al., 1999). Some other benefits include increased faecal bulk and increased excretion of butyrate and acetate. Besides physiological benefits in human, RS has been reported to have potential as a unique ingredient that can yield high-quality foods. For example, application tests of RS showed improved crispness and expansion in certain products and better mouthfeel, colour, and flavour as compared with products produced with traditional, insoluble fibres (Yue and Waring, 1998; Milasinovic et al., 2010; Sharma et al., 2016).

Classification of $\mathrm{RS}$ is generally made into four categories $\left(\mathrm{RS}_{1}-\mathrm{RS}_{4}\right)$ based on the mechanism that contributes to their resistance to digestion (Sajilata et al., 2006). $\mathrm{RS}_{1}$ is the starch that escapes digestion because it is physically inaccessible by entrapment in a nondigestible matrix, they are found in partly milled grains, seeds, and legumes. $\mathrm{RS}_{2}$ consists of raw starch granules (ungelatinized) which have retained their crystal structure; therefore, they are not attacked by digestive enzymes, they are found in raw potato, banana, and highamylose corn starches. $\mathrm{RS}_{3}$ consists mainly of retrograded or recrystallized amylose (Garcia-Alonso et al., 1999), this can be found in bread, corn flakes, or potatoes. $\mathrm{RS}_{4}$ can be produced by chemical 
modifications, such as conversion, substitution, or crosslinking. Such modifications prevent digestion of $\mathrm{RS}_{4}$ by blocking access to enzymes and by forming typical linkages, examples are starch phosphates, hydroxypropyl starches, starch acetates and citrate (Wepner et al., 1999; Dundar and Gocmen, 2013).

Among different resistant starches, retrograded resistant starch $\left(\mathrm{RS}_{3}\right)$ has great commercial importance since its crystalline polymorphs exhibit an endothermic transition from 120 to $165^{\circ} \mathrm{C}$ that typically survives most, but not all, food processing conditions (Milasinovic et al., 2009). The degree of formation of RS in foods depends on the type of starch, processing condition adopted and is also influenced by the duration and storage conditions (Chou et al., 2014). Processing techniques include baking, pasta production, extrusion cooking, steam cooking, autoclaving and others (Sajilata et al., 2006). Autoclaving has been reported in the formation of resistant starch from maize starch, high amylose corn starch, pulses and in cassava (Sajilata et al., 2006).

Commercially, the starches used in preparing $\mathrm{RS}_{3}$ are derived from high amylose corn starch containing greater than $40 \%$ amylose. The current trend in this research area is the investigation of alternative sources for RS production. Resistant starch had been produced from different local crops like sago, maize, banana, rice and cassava (Mohamed et al., 2008; Pongjanta et al., 2008; Vatanasuchart et al., 2009). Native cassava starch contains amylose which ranges from 19.6 to $24.1 \%$. It has been reported to be suitable after amylopectin debranching (Worawikunya, 2007; Mutungi et al., 2009 and Vatanasuchart et al., 2010). Nigeria is the world's largest producer of cassava. It has been estimated that Nigeria's production of cassava reached 45 million tonnes annually. The country has consistently been ranked as the world's largest producer of cassava since 2005 (FAOSTAT, 2012). Thus, making cassava starch a good choice for RS formation, with potentials as a food ingredient for manufacturing health food.

However, there is scanty information on the influence of autoclaving on the formation of resistant starch from cassava starch especially from Nigerian Cassava varieties. The main objective of this research work was to explore the availability of improved varieties of cassava in Nigeria, in the production of resistant starch to enhance the use of cassava starch as a functional food and an industrial product. Thus, this study evaluated the effects of isoamylase debranching, different autoclaving condition and storage on the formation of resistant starch.

\section{Materials and methods}

\subsection{Materials}

The varieties of cassava used for this research work were TMS 30572 and 98/0581 which were obtained from the International Institute of Tropical Agriculture (IITA) Ibadan. This selection was based on the percentage yield and amylose content of cassava mosaic disease-resistant cassava clones as reported by Sanni et al. (2008). The enzymes used were commercial isoamylase obtained from Pseudomonas $s p$. and was purchased from SigmaAldrich, Steinheim, Germany; Amyloglucosidase (EC. 3.2.1.3 from Aspergillus niger, 11, $500 \mathrm{U} / \mathrm{mL}$ ) and pancreatic- $\alpha$-amylase which were obtained from SIGMA U.S. All the chemicals used were of analytical grade.

\subsection{Methods}

\subsubsection{Starch extraction}

Starch was extracted from these two varieties of cassava using the standard methods of starch extraction (IITA, 1990). About $1 \mathrm{~kg}$ of fresh cassava tubers from each variety was used. The tubers were peeled, washed, grated with the grating machine (DANDREA agrimport, model: 59911) and in excess of water, filtered through a muslin cloth. The filtrate was stirred with a stirring rod for $2 \mathrm{~min}$ and allowed to stand for $1 \mathrm{~h}$ to facilitate starch sedimentation. The top liquid was decanted and discarded. The water was changed several times to avoid fermentation. The remaining moist starch was then stirred up with water and washed several times to obtain a reasonably clean starch paste. The starch paste was thinly spread on trays and dried in a cabinet dryer (Model LEEC F2). The cabinet dryer consists of an insulated chamber fitted with perforated trays. The drying process was achieved at a temperature of $50^{\circ} \mathrm{C}$ for about $10 \mathrm{hrs}$. The dried cassava starch samples were milled on a micro mill, sifted through $212 \mu \mathrm{m}$ sieve and kept in zip-lock bags for further analyses.

\subsubsection{Enzymatic debranching of cassava starch}

The debranching of the cassava starch was carried out as described by Mutungi et al. (2009). Prior to debranching, the optimal concentration of isoamylase enzyme was determined. Cassava starch samples were debranched with enzyme isoamylase; an aqueous starch slurry $(20 \% \mathrm{w} / \mathrm{v})$ was cooked in a pan on an electric element at a temperature of $85^{\circ} \mathrm{C}$ with continuous stirring for 15 mins and autoclaved at $121^{\circ} \mathrm{C}$ for $15 \mathrm{mins}$ (pressure of $1.94 \mathrm{~atm}$ ). The starch gel was suspended with $50 \mathrm{mmol} / \mathrm{L}$ sodium acetate buffer $\mathrm{pH} 3.5$ to obtain the gel of $7.5 \% \mathrm{w} / \mathrm{v}$. The gel was cooled to $50^{\circ} \mathrm{C}$ and 90 $\mathrm{mU} / \mathrm{g}$ starch of isoamylase enzyme was added. The suspension was incubated in a shaking water bath at $50^{\circ}$ $\mathrm{C}$ for $12 \mathrm{hrs}$. Enzyme activity was terminated by heating 
at $85^{\circ} \mathrm{C}$ for 30 mins. The sample was then cooled to room temperature. Both the debranched and undebranched samples were then freeze-dried (Labconco FreeZone Plus 4.5 Liter Cascade Console Freeze Dry Systems (Kansas City, MO) and packaged until further analyses.

\subsubsection{Production of resistant starch by autoclaving}

The debranched and undebranched starch samples were subjected to autoclaving using the method of Milasinovic et al. (2009). Starch suspension was made at starch-to-water ratio of 1:1,1:3, and 1:5 with distilled water. The suspensions were autoclaved at temperatures of $110^{\circ} \mathrm{C}$ and $121^{\circ} \mathrm{C}$ for 15 mins. The autoclaving and cooling of samples were done in four cycles (Sangick et al., 2004). Samples were then subsequently cooled to room temperature with subsequent storage for $0 \mathrm{hrs}, 24$ $\mathrm{hrs}$ and $48 \mathrm{hrs}$ under refrigeration temperature $\left(5-7^{\circ} \mathrm{C}\right)$ and freezing temperature $\left(-28^{\circ} \mathrm{C}\right)$. The samples were dried in a commercial oven dryer at $45^{\circ} \mathrm{C}$ for a maximum of $12 \mathrm{hrs}$, pulverized to a fine particle size by a micro mill, sifted through $212 \mu \mathrm{m}$ sieve and kept in Zip -lock bags for further analyses.

\subsection{Resistant starch determination}

Resistant starch content was determined as described by McCleary et al. (2002). About $100 \mathrm{mg}$ of the sample was weighed into a $50 \mathrm{~mL}$ centrifuge tube and $4 \mathrm{~mL}$ of $1.0 \mathrm{M}$ sodium maleate buffer $(\mathrm{pH}$ 6.0) containing pancreatic $\alpha$-amylase $(10 \mathrm{mg} / \mathrm{ml})$ and amyloglucosidase ( $3 \mathrm{U} / \mathrm{ml}$ ) was added, the tube was covered with paraffin film, mixed and placed horizontally in a shaking water bath. The solution was incubated at $37^{\circ} \mathrm{C}$ with continuous shaking for $16 \mathrm{hrs}$. To the solution was added $4 \mathrm{~mL}$ of $99 \%$ ethanol to precipitate the starch and mixed vigorously on a vortex mixer. It was centrifuged at 1500 rpm for 10 mins. The supernatant was decanted and the residue rinsed twice with $8 \mathrm{~mL} 50 \%$ ethanol, followed by centrifugation at 3,000 rpm for 10 mins. The residue was re-suspended with $2 \mathrm{~mL}$ of $2 \mathrm{M}$ potassium hydroxide in an ice bath with stirring for 20 mins and $8 \mathrm{~mL}$ of $1.2 \mathrm{M}$ sodium acetate buffer ( $\mathrm{pH} 3.8$ ) was added with $0.1 \mathrm{~mL}$ of amyloglucosidase $(3300 \mathrm{U} / \mathrm{ml})$. The sample was mixed and incubated at $50^{\circ} \mathrm{C}$ with continuous shaking for 30 mins. The sample was then diluted with water and centrifuged at 3,000 rpm for 10 mins. The glucose was quantified with glucose oxidase/peroxidase reagent (GOPOD), which gave a measure of the RS content of the sample.

\subsection{Statistical analysis}

All data were subjected to analysis of variance (ANOVA) using Statistical Analysis System Institute version 9.2 package. Means were separated using LSD Test (DMRT, 1955) at 5\% level of probability.

\section{Results and discussion}

\subsection{Effect of debranching on formation of resistant starch}

RS obtained from debranched cassava starch had more than $70 \%$ increase in resistant starch contents as shown in Tables 1 and 2 . The debranching process partially debranched amylopectin molecules of the cassava starch and consequently providing small linear fragments and small clusters of the amylopectin molecules for retrogradation/recrystallization and hence the formation of more resistant starch. This is in line with reports of Berry (1986), Vatanasuchart et al. (2010) and Babu and Parimalavalli (2018) who reported that debranching of amylopectin with pullulanase before

Table 1 . Effect of autoclaving at $110^{\circ} \mathrm{C}$ on formation of resistant starch content $(\mathrm{g} / 100 \mathrm{~g})$

\begin{tabular}{cccccccc}
\hline \multirow{2}{*}{ Variety } & \multirow{2}{*}{ Cooling cycle } & \multicolumn{3}{c}{ Undebranched } & \multicolumn{3}{c}{ Debranched } \\
\cline { 2 - 7 } & & $1: 1$ & $1: 3$ & $1: 5$ & $1: 1$ & $1: 3$ & $1: 5$ \\
\hline \multirow{2}{*}{30572} & 1 & $6.21^{\mathrm{d}}$ & $6.07^{\mathrm{f}}$ & $6.24^{\mathrm{d}}$ & $22.63^{\mathrm{e}}$ & $22.47^{\mathrm{c}}$ & $22.51^{\mathrm{e}}$ \\
& 2 & $7.52^{\mathrm{c}}$ & $7.39^{\mathrm{d}}$ & $7.54^{\mathrm{b}}$ & $24.31^{\mathrm{c}}$ & $23.79^{\mathrm{b}}$ & $23.95^{\mathrm{c}}$ \\
& 4 & $9.07^{\mathrm{a}}$ & $9.01^{\mathrm{b}}$ & $9.14^{\mathrm{a}}$ & $25.93^{\mathrm{a}}$ & $25.31^{\mathrm{a}}$ & $23.43^{\mathrm{a}}$ \\
$98 / 0581$ & 1 & $6.18^{\mathrm{d}}$ & $6.19^{\mathrm{e}}$ & $6.11^{\mathrm{d}}$ & $22.41^{\mathrm{f}}$ & $22.52^{\mathrm{c}}$ & $22.30^{\mathrm{e}}$ \\
& 2 & $7.51^{\mathrm{c}}$ & $7.52^{\mathrm{c}}$ & $7.45^{\mathrm{c}}$ & $23.74^{\mathrm{d}}$ & $23.84^{\mathrm{b}}$ & $23.63^{\mathrm{d}}$ \\
& 4 & $8.98^{\mathrm{b}}$ & $9.17^{\mathrm{a}}$ & $8.96^{\mathrm{a}}$ & $25.27^{\mathrm{b}}$ & $25.30^{\mathrm{a}}$ & $25.12^{\mathrm{b}}$ \\
\hline
\end{tabular}

Means with the same alphabet in the same column are not significantly different $(p>0.05)$

Table 2. Effect of autoclaving at $121^{\circ} \mathrm{C}$ on formation of resistant starch content $(\mathrm{g} / 100 \mathrm{~g})$

\begin{tabular}{cccccccc}
\hline \multirow{2}{*}{ Variety } & \multirow{2}{*}{ Cooling cycle } & \multicolumn{3}{c}{ Control } & \multicolumn{3}{c}{ Debranched } \\
\cline { 2 - 7 } & & $1: 1$ & $1: 3$ & $1: 5$ & $1: 1$ & $1: 3$ & $1: 5$ \\
\hline \multirow{2}{*}{30572} & 1 & $6.70^{\mathrm{d}}$ & $6.52^{\mathrm{c}}$ & $6.15^{\mathrm{e}}$ & $22.90^{\mathrm{c}}$ & $22.70^{\mathrm{d}}$ & $22.41^{\mathrm{c}}$ \\
& 2 & $7.90^{\mathrm{c}}$ & $7.87^{\mathrm{b}}$ & $7.35^{\mathrm{d}}$ & $24.34^{\mathrm{b}}$ & $23.92^{\mathrm{c}}$ & $23.63^{\mathrm{b}}$ \\
& 4 & $9.21^{\mathrm{b}}$ & $9.19^{\mathrm{a}}$ & $8.82^{\mathrm{b}}$ & $25.72^{\mathrm{a}}$ & $25.40^{\mathrm{a}}$ & $25.12^{\mathrm{a}}$ \\
$98 / 0581$ & 1 & $6.79^{\mathrm{c}}$ & $6.50^{\mathrm{c}}$ & $6.21^{\mathrm{e}}$ & $23.01^{\mathrm{c}}$ & $22.71^{\mathrm{d}}$ & $22.43^{\mathrm{c}}$ \\
& 2 & $8.07^{\mathrm{b}}$ & $7.75^{\mathrm{b}}$ & $7.90^{\mathrm{c}}$ & $24.33^{\mathrm{b}}$ & $23.92^{\mathrm{c}}$ & $23.86^{\mathrm{b}}$ \\
& 4 & $9.64^{\mathrm{a}}$ & $9.21^{\mathrm{a}}$ & $9.13^{\mathrm{a}}$ & $25.97^{\mathrm{a}}$ & $24.80^{\mathrm{a}}$ & $25.40^{\mathrm{a}}$ \\
\hline
\end{tabular}

Means with the same alphabet in the same column are not significantly different $(p>0.05)$ 
subjecting it to heating and cooling cycles substantially increased the RS content and this was attributed to an increase in the content of linear starch chains as a result of debranching.

\subsection{Effect of autoclaving on formation of resistant starch}

The result of the resistant starch content obtained from autoclaving at $110^{\circ} \mathrm{C}$ is as shown in Tables 1 . RS content obtained with starch/water ratio of $1: 1$ for the undebranched starch sample was 6.21 and $6.18 \mathrm{~g} / 100 \mathrm{~g}$, respectively, for TMS 30572 and TMS 98/0581. The RS contents increased to 9.07 and $8.98 \mathrm{~g} / 100 \mathrm{~g}$ after four heat and cool cycles. RS of debranched samples increased from 22.63 and 22.41 to 25.93 and $25.27 \mathrm{~g} / 100$ $\mathrm{g}$ in TMS 30572 and TMS 98/0581, respectively. The same trend was observed in the samples with starch/ water ratio of $1: 3$ and 1:5. RS content increased significantly $(p<0.05)$ with heat and cool cycles, while there were differences in the resistant starch content with effect of starch/water ratio but not all, were significant $(p>0.05)$. Highest RS obtained for the undebranched and the debranched sample was $9.17 \mathrm{~g} / 100 \mathrm{~g}$ and $25.93 \mathrm{~g} / 100$ $\mathrm{g}$, respectively.

The RS contents increased more than $18 \%$ for all the starch/water ratios after four autoclaving heat and cool cycles. This is in line with the other reports that the formation of RS in maize starch was affected by a number of autoclaving heat and cool cycles (Sajilata et al., 2006; Koksel et al., 2007, Ozturk et al., 2011; Dundar and Gocmen, 2013). Milašinović et al. (2009) also reported that the starch/water ratio did not significantly affect the RS yields but the number of autoclaving heat and cool cycles did. Repeated heat/ moisture treatments have been reported to have effects on the hydrolysis limit of pancreatic $\alpha$-amylase and hence increase in RS (Haralampu, 2000).

The values of the resistant starch obtained from autoclaving at $121^{\circ} \mathrm{C}$ are as shown in Table 2. The values of resistant starch with starch/water ratio of $1: 1$ for the debranched starch sample ranged between 6.70 and 9.21 and 6.79 and $9.64 \mathrm{~g} / 100 \mathrm{~g}$, in TMS 30572 and TMS 98/0581, respectively. There were increases in the resistant starch content with the increase in the number of autoclaving heat and cool cycles and these increases were significant $(p<0.05)$. Higher values of resistant starch contents were recorded for samples autoclaved at $121^{\circ} \mathrm{C}$ than those autoclaved at $110^{\circ} \mathrm{C}$ and the differences were significant $(p<0.05)$. The mean effects of autoclaving temperatures on the resistant starch contents confirmed that higher autoclaving temperature has a beneficial impact on resistant starch formation as reported by Dundar and Gocmen (2013) who studied the effects of autoclaving temperatures on the formation of resistant starch.

\subsection{Effect of storage on formation of $R S$}

The effect of storage on formation of RS was determined using the starch sample steam cooked at $121^{\circ}$ $\mathrm{C}$ with starch water ratio 1:1 heated and cooled after four times stored under refrigeration and freezing conditions for $48 \mathrm{hrs}$ based on the resistant starch contents. The result is as shown in Figure 1. Storage both at refrigeration and freezing conditions increased the formation of RS. The longer the storage time the higher the RS contents, indicating that storage condition and time had effects on the formation of resistant contents. This is in line with previous findings that low storage temperature increased the resistant starch content while the major changes had been attributed to retrogradation of starch (Kavita et al., 1998; Namratha et al., 2002; Agama Acevedo et al., 2004; Ramakrishnan, 2009; Jagannadham et al., 2017). The highest RS value obtained was $9.72 \mathrm{~g} / 100 \mathrm{~g}$ and $26.52 \mathrm{~g} / 100 \mathrm{~g}$ for both undebranched and debranched samples, respectively which were obtained under refrigeration after $48 \mathrm{hrs}$ of storage.

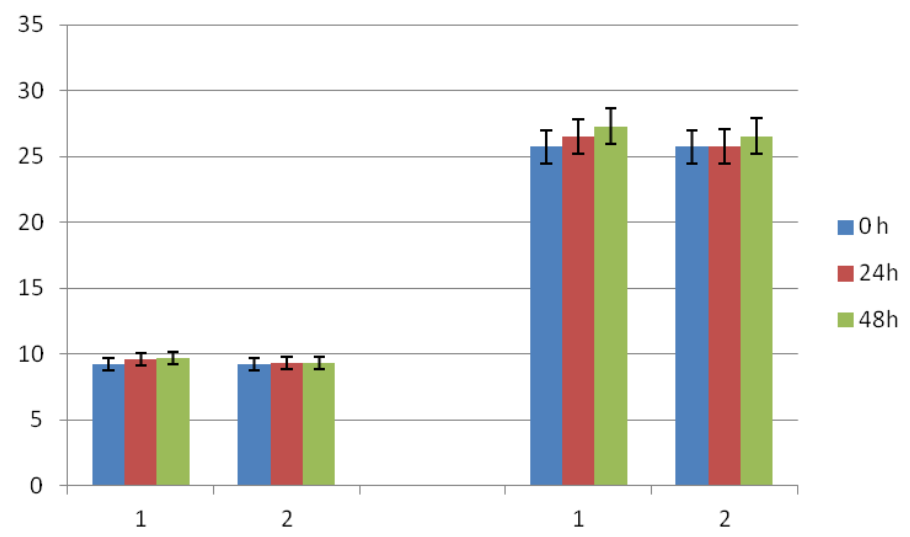

Figure 1. Effect of storage condition on formation of RS in undebranched and debranched starch samples. 1 Refrigerated samples. 2 - Frozen samples.

\section{Conclusion}

Based on the research carried out, it could be inferred that the variety, debranching process, autoclaving temperature and storage conditions and time had effects on the formation of resistant starch. A debranching process with isoamylase is suitable for partially debranching amylopectin molecules of the cassava starch. Autoclaving at the temperature of $121^{\circ} \mathrm{C}$ had higher yield of resistant starch contents than the samples autoclaved at $110^{\circ} \mathrm{C}$. Heat and cool cycles and storage condition had effects on the formation of RS.

\section{References}

Agama-Acevedo, E., Rendon-Villalobos, R., Tovar, J., 
Parades-Lopez, O., Islas-Hernandez, J.J. and Bello Perez, L. (2004). In-vitro starch digestibility changes during storage of maize flour tortillas. Nahrung/ Food, 48(1), 38-42.

Azzurra, A. and Paola, A. (2009). Consumers' behaviours and attitudes toward healthy food products: The case of organic and functional foods. $113^{\text {th }}$ Seminar of European Association of Agricultural Economists (EAAE) on Food industry and Food chain, September 3-6, 2009, Chania, Crete, Greexe.

Babu. A.S. and ParimalavallI, R. (2018). Effect of pullulanase debranching and storage temperatures on structural characteristics and digestibility of sweet potato starch. Journal of Saudi Society of Agricultural Sciences, 17(2), 208-216. https:// doi.org/10.1016/j.jssas.2016.04.005

Bae, C.-H., Park, M.-S., Ji, G.-E. and Park, H.-D. (2013). Effects of Phosphorylated Cross-linked Resistant Corn Starch on the Intestinal Microflora and Short Chain Fatty Acid Formation during In vitro Human Fecal Batch Culture. Food Science and Biotechnology, 22(6), 1649-1654. https:// doi.org/10.1007/s10068-013-0262-y

Baghurst, P.A., Baghurst, K.I. and Record, S.J. (1996) Dietary fibre, non-starch polysaccharides and resistant starch-a review. Supplement to Food Australia, 48(3), S1-S36.

Berry, C.S. (1986). Resistant starch: formation and measurement of starch that survive exhaustive digestion with amylolytic enzymes during the determination of dietary fiber. Journal of Cereal Science, 4(4), 301-314. https://doi.org/10.1016/ S0733-5210(86)80034-0

Champ, M., Matin, L., Noah, L. and Gratas, M. (1999). Analytical methods for resistant starch. Complex Carbohydrates in Foods, 169-187.

Champ, M.M. (2004). Physiological aspects of resistant starch and in vivo measurements. Journal of the Association of Official Analytical Chemists International, 87(3), 749-755.

Chou, C., Tsaifa, Y. and Chengta, Li. (2014). Effects of different cooking methods and particle size on resistant starch content and degree of gelatinization of a high amylose rice cultivar in Taiwan. Journal of Food, Agriculture and Environment, 12(2), 6 -10.

Dundar, A.N. and Gocmen, D. (2013). Effects of autoclaving temperature and storing time on resistant starch formation and its functional and physicochemical properties. Carbohydrate Polymer, 97(2), 764-771. https://doi.org/10.1016/ j.carbpol.2013.04.083
Englyst, H.N., Kingman, S.M. and Cummings, J.H. (1992). Classification and measurement of nutritionally important starch fractions. European Journal of Clinical Nutrition, 46(Suppl. 2), S33-S50.

FAOSTAT. (2012). The world production of cassava roots in 2012 (FAO). Retrieved from FAOSTAT website: http://www.fao.org.

Garcia-Alonso, A., Jimenez-Escrig, A., Martin-Carron, N., Bravo, L. and Saura-Calixto, F. (1999). Assessment of some parameters involved in the gelatinization and retrogradation of starch. Food Chemistry, 66, 181-187. https://doi.org/10.1016/ S0308-8146(98)00261-1

Haralampu, S.G. (2000). Resistant starch-a review of the physical properties and biological impact of $\mathrm{RS}_{3}$. Carbohydrate Polymers, 41(3), 285-292. https:// doi.org/10.1016/S0144-8617(99)00147-2

IITA International Institute of Tropical Agriculture, Ibadan, Nigeria (1990). Post-harvest Technology. In Cassava in Tropical Africa. A Reference manual. Retrieved from website: http://www.iita.org/wpcontent/uploads/2016/06/

Cassava_in_tropical_Africa_a_reference_manual_19 90.pdf

Jagannadham, K., Parimalavalli, R. and Babu, A.S. (2017). Effect of triple retrogradation treatment on chickpea resistant starch formation and its characterization. Journal of Food Science and Technology, 54(4), 901-908. https://doi.org/10.1007/ s13197-016-2308-7

Kavita, V., Varghese, S., Chitra, G.R. and Jamuna P. (1998). Effects of processing, storage time and temperature on the resistant starch of foods. Journal of Food Science and Technology, 35(4), 299-304.

Koksel, H., Basman, A., Kahraman, K. and Ozturk, S. (2007). Effect of acid modification and heat treatments on resistant starch formation and functional properties of corn starch. International Journal of Food Properties, 10, 691-702. https:// doi.org/10.1080/10942910601128887

McCleary, B.V. and Monaghan, D.A. (2002). Measurement of resistant starch. Journal of the Association of Official Analytical Chemists International, 85(3), 665-675.

Milasinovic, M.S., Radosavljevic, M.M. and Dokic, L.P. (2010). Effects of autoclaving and pullulanase debranching on the resistant starch yield of normal maize starch. Journal of Serbian Chemical Society, 75, 449-458. https://doi.org/10.2298/ JSC090904027M

Mohamed, A., Jamilah, B., Abbas, K.A., Abdul Rahman, R. and Roselina, K. (2008). A review on 
physicochemical and thermorheological properties of sago starch. American Journal of Agricultural and Biological Sciences, 3(4), 639-646. https:// doi.org/10.3844/ajabssp.2008.639.646

Muir, J.G. and O'Dea, K. (1993). Measurement of resistant starch: factors affecting the amount of starch escaping digestion in vitro. American Journal of Clinical and Nutrition, 56, 123-127. https://doi.org/10.1093/ajcn/56.1.123

Mutungi, C., Onyango. C., Jaros. D., Henle. T. and Rohm. H. (2009). Determination of optimum conditions for enzymatic debranching of cassava starch and synthesis of resistant starch type III using central composite rotatable design. Starch/Stärke, 61, 367-376. https://doi.org/10.1002/star.200800119

Namratha, J., Asna, U. and Prasad, N.N. (2002). Effect of storage on resistant starch content of processed ready-to-eat foods. Food Chemistry, 79(3), 395-400. https://doi.org/10.1016/S0308-8146(02)00210-8

Öztürk, S. and Köksel, H. (2014) Production and characterisation of resistant starch and its utilisation as food ingredient: a review. Quality Assurance and Safety of Crops and Foods, 6(3), 335-346. https:// doi.org/10.3920/QAS2013.0367

Pongjanta J., Utaipattanaceep, A., Naivikul, O. and Piyachomkwan, K. (2008). Enzymes-Resistant Starch (RS III) from pullulanase-debranched high amylose rice starch. Kasetsart Journal (Natural Science), 42, 198-205.

Raben, A., Tagliabue, A., Christensen, N.J., Madsen, J., Holst J.J. and Astrup, A. (1994). Resistant Starch: the effect on postprandial glycemia, hormonal response and satiety. American Journal of Clinical and Nutrition, 60, 544-551. https://doi.org/10.1093/ ajcn/60.4.544

Ramakrishnan, Y. (2009). Effects of different cooking methods and storage conditions on the rice starch digestibility. Malaysia: University of Putra Malaysia, MSc. Thesis.

Ranhotra, G.S., Gelroth, J.A. and Glaser B.K. (1996). Effect of resistant starch on blood and liver lipids in hamsters. Cereal Chemistry, 73(2), 176-178.

Sajilata, M.G., Singhal, R.S. and Kulkarni, P.R. (2006). Resistant starch - A review. Comprehensive Reviews in Food Science and Food Safety, 5, 1-17. https:// doi.org/10.1111/j.1541-4337.2006.tb00076.x

Sangick, S., Jaeeon, B., Kwan, H.P. and Tae, W.M. (2004). Effect of partial acid hydrolysis and heatmoisture treatment on formation of resistant tuber starch. Journal of Cereal Chemistry, 81(2), 194198. https://doi.org/10.1094/CCHEM.2004.81.2.194

Sanni, L.O., Adebowale, A.A., Maziya-Dixon, B. and
Dixon, A.G.O. (2008). Chemical composition and pasting properties of CMD resistant cassava clones planted at different locations. Journal of Food, Agriculture and Environment, 6(2), 97-104.

Schwiertz, A., Lehmann, U., Jacobasch, G. and Blaut, M. (2002). Influence of resistant starch on the SCFA production and cell counts of butyrate producing Eubacterium spp. in the human intestine. Journal of Applied Microbiology, 93, 157-162. https:// doi.org/10.1046/j.1365-2672.2002.01679.x

Sharma, S., Singh, N. and Katyal, M. (2016). Effect of gelatinized-retrograded and extruded starches on characteristics of cookies, muffins and noodles. Journal of Food Science and Technology, 53(5), 2482-2491. https://doi.org/10.1007/s13197-0162234-8

Topping, D.L and Clifton, P.M. (2001). Short chain fatty acids and human colonic function: Roles of resistant starch and non-starch polysaccharides. Physiological Reviews-American Journal of Physiology, 81, 1031-1064. https://doi.org/10.1152/ physrev.2001.81.3.1031

Vatanasuchart, N., Niyomwit, B. and Wongkrajang, K. (2009). Resistant starch contents and the in vitro starch digestibility of Thai starchy foods. Kasetsart Journal (Natural Science), 43, 178-186.

Vatanasuchart, N., Tungtrakul, P., Wongkrajang, K. and Naivikul, O. (2010). Properties of pullulanase debranched cassava starch and type-III resistant starch. Kasetsart Journal (Natural Science), 44, 131141.

Wepner, B., Berghofer, E., Miesenberger, E., Tiefenbacher, K. (1999). Citrate starch: Application as resistant starch in different food systems. Starch/ Stärke, 51, 354-361. https://doi.org/10.1002/(SICI) 1521-379X(199910)51:10<354::AIDSTAR354>3.0.CO;2-W

Worawikunya, K. (2007). Production of enzymeresistant starch from cassava starch. Thailand: Suranaree University of Technology, MSc. Thesis.

Yue, P. and Waring, S. (1998). Resistant starch in food applications. Cereal Foods World, 43(9), 690-695. 